\title{
PAI NOSSO QUE ESTÁS NOS CÉUS Um Estudo Bíblico-Teológico da Invocação Inicial do Pai-Nosso
}

\author{
Prof. Dr. Matthias Grenzer
}

\section{RESUMO}

Este artigo apresenta um estudo bíblico-teológico da invocação inicial do Pai-Nosso.

Palavras chave: Pai, Céu, Espiritualidade bíblica.

\begin{abstract}
In this article is realized a biblical-theological study of the initial invocation of the "Our Father".

Key-words: Father, Heaven, Biblical Spirituality.
\end{abstract}

\section{AS DUAS VERSÕES DO APELO INICIAL}

A oração ensinada por Jesus começa com um apelo: Pai nosso que estás nos céus (Mt 6,9b) ou, simplesmente, Pai (Lc 11,2). ${ }^{1}$ Talvez o evangelista Lucas, por apresentar o texto menor, transmita a versão mais de acordo com as palavras originalmente formuladas por Jesus. Pois, imaginase, de um modo mais fácil, que o evangelista Mateus tenha acrescentado alguns elementos do que Lucas ter omitido palavras que Jesus, de fato, teria ensinado. Todavia, trata-se de uma hipótese literário-histórica a respeito da versão provavelmente mais original do Pai-Nosso. É uma questão legítima, uma vez que se observam diferenças entre as versões de Mateus e Lucas. Em contrapartida, não há como ter certeza plena sobre o caso. E talvez nem

1 O recurso gráfico da "letra inclinada" (itálico) é reservado às citações bíblicas. 
seja necessário. Basta respeitar a circunstância de que se encontram duas versões do Pai-Nosso no Novo Testamento. Assim, o leitor é chamado a compreender, paralelamente, a versão mais comprida do evangelista Mateus e a forma mais curta apresentada pelo evangelista Lucas.

\section{DEUS PAI NO ANTIGO TESTAMENTO}

Ao chamar Deus de Pai, é provável que Jesus tenha tido na memória as tradições religiosas de seu povo. Vamos realizar um estudo de suas Sagradas Escrituras, ou seja, daquela parte da Bíblia que os cristãos chamam de Antigo Testamento.

Dois nomes hebraicos bastante antigos são interessantes de observar. O filho de Samuel - juiz e profeta no século XI a.C. - chama-se Abias, que significa o Senhor (= Javé) é meu pai (cf. 1Sm 8,2). Também o filho do rei Jeroboão (927-907 a.C.) carregou este nome (1Rs 14,1). Além disso, conforme $1 \mathrm{Cr}$ 13,1, Abias era o nome de um rei de Judá (910 a 908 a.C). O outro nome interessante é Joab, com o significado de o Senhor (= Javé) é pai. Veja, sobretudo, Joab, sobrinho de Davi (1Cr 2,16).

Além destes dois nomes, há textos no Antigo Testamento, nos quais o comportamento do Senhor Deus é comparado à atitude de um pai humano. Veja SI 103,13: Como um pai é compassivo com os filhos, o Senhor sentiu compaixão com aqueles que o temem. Observe também $\operatorname{Pr} 3,12$ : Pois o Senhor repreende aqueles que ama, como um pai é favorável a seu filho.

Outro elemento merece ser contemplado neste contexto. No Antigo Testamento, Israel é apresentado como filho primogênito do Senhor (cf. Ex 4,22; Os 11,1). Onde, porém, há um filho, também há um pai. Basta ler Jr 31,9: Pois me tornei Pai para Israel; e Efraim: ele é meu primogênito.

Contudo, a relação do Pai divino com seus filhos passou por decepções e recuperações no relacionamento. Assim, o Senhor fala em Is 1,2: Criei filhos, os fiz crescer: mas perverteram-se, contra mim! Veja também o oráculo do Senhor em Jr 3,19-20: E eu dizia: vós me chamareis "Meu Pai" e não vos afastareis de mim. Mas como a mulher traiu o companheiro dela, assim me traístes, oh casa de Israel. Aqui cabe também lembrar o Cântico de Moisés: É isto que devolveis ao Senhor, oh povo estúpido e pouco sábio? Ele não é teu Pai? Te criou, te fez e te firmou! (Dt 32,6). 
Não obstante, por mais que os filhos tenham mentido, se obstinado e abandonado o espírito da santidade do Senhor - com a conseqüência de seu Deus se transformar em inimigo deles -, o Pai se lembra também dos dias antigos (Is 63,8.10-11). Por isso, existe sempre a possibilidade de os filhos apelarem á paternidade de seu criador: De fato, tu és nosso Pai! Ainda que Abraão não nos conhecesse e Israel não nos identificasse, tu, oh Senhor, és nosso Pai, nosso redentor. Este é teu nome desde sempre (Is 63,16). Ou seja: o profeta não consegue imaginar que quem criou possa se desfazer definitivamente de sua criação. Neste sentido, deixa o povo de Deus dizer: Então, tu Senhor, és nosso Pai! Nós somos a argila e tu és nosso oleiro! A obra de tuas mãos somos todos nós! (Is 64,7).

Um último detalhe das tradições contidas no Antigo Testamento seja ainda lembrado: na opinião do profeta, o Santo e Criador de Israel não pode ser criticado por causa de seus filhos. Pelo contrário: Ai daquele que diz a um pai: por que geras? (Is 45,10-11). ${ }^{2}$

Resumindo: ao chamar Deus de Pai, Jesus movimenta-se dentro das possibilidades que a linguagem religiosa de seu povo judeu the oferece. Seja lembrado ainda o texto hebraico de Eclo 51,10: Oh Senhor, tu és meu pai, pois tu és o herói de minha salvação. Outros textos do judaísmo nos séculos II e I a.C. - textos que não entraram no cânon das Sagradas Escrituras - poderiam ser mencionados. No entanto, é suficiente neste momento destacar que Jesus chama de Pai aquele Deus que, desde sempre, já era Pai de Israel. ${ }^{3}$

Com isso, por sua vez, Jesus traz à memória a história do povo de Deus e seu relacionamento muitas vezes conturbado com o criador. Ou seja: a expressão Pai deixa imaginar uma convivência dinâmica, marcada por sofrimentos causados pelos filhos, exatamente como o indica a experiência dos pais humanos no dia-a-dia. Todavia, existe a esperança de que Deus Pai nunca se afaste definitivamente de sua criação, mas faça prevalecer sua compaixão e vontade de redenção. Que o Pai seja, sobretudo, misericordioso com seus filhos (cf. Lc 15,11-32).

2 Cf. Ferdinand Staudinger, Pai. In: Johannes B. Bauer, Dicionário Bíblico-Teológico. São Paulo, Loyola, 2000. p. 295-297.

3 Cf. Peter Fiedler, Gottes Vergebungsbereitschaft und Heilswille, p. 187. In: Ludger Schenke e outros. Jesus von Nazaret - Spuren und Konturen. Stuttgart, Kohlhammer, 2004. p. 164192. 


\section{QUEM É A MÃE?}

Por que Jesus chama Deus de Pai e não de 'mãe'? De fato, o Antigo Testamento fala dos traços maternos de Deus. Veja Is 49,15: Por acaso uma mulher se esquece de seu lactante? É quem se compadece do filho de seu ventre! Ainda que ela se esquecesse, eu - isto é, o Senhor - não me esquecerei de ti. Compara-se o comportamento do Deus bíblico à atitude de uma mãe. Confira também Is 66,13: Como a um homem que sua mãe consola, assim eu os consolarei.

Não obstante, as tradições religiosas do Antigo Israel "nunca chamam Deus diretamente de mãe". ${ }^{4}$ A razão disso encontra-se na circunstância de que, em relação a seu povo, Deus é imaginado diversas vezes como esposo ou amado, enquanto Israel é descrito como mulher, prostituta, virgem, noiva, amada, ou seja, sempre como a parte feminina (cf. Jr 2-3; Ez 16; Os 2; Ct). Deus, porém, ocupa a parte masculina dentro da lógica interna deste imaginário. É exatamente em conseqüência disso que pode ser chamado somente de $P a i$, e não de mãe.

\section{O PAI DE JESUS}

O que Jesus imaginava mais exatamente quando chamou Deus de Pai, usando a palavra aramaica abba (cf. Mc 14,36; Rm 8,15; GI 4,6)? É interessante ler os Evangelhos com esta questão em mente, observando as múltiplas afirmações de Jesus sobre o Pai.

Vê-se, por primeiro, que Jesus insiste na atitude providente do Pai celeste. Trata-se de um Pai que dá coisas boas (Mt 7,11), por conhecer as necessidades do homem (Mt 6,8.32; Lc 12,30). Ou, com outras palavras: - Pai celeste propõe-se a alimentar e vestir os seus, querendo poupar a pessoa da ansiedade diária pela sobrevivência (Lc 12,22-32; Mt 6,26). Mais ainda: Jesus afirma que o Pai celeste se preocupa especialmente com as pessoas humildes, consideradas pequenas. Diz que nenhum dos pequenos será perdido, uma vez que os anjos deles contemplam constantemente a face do Pai nos céus (Mt 18,1-14). O homem, por sua vez, é convidado a

4 Gerhard Lohfink, Das Vaterunser neu ausgelegt. Bad Tölz, Urfeld, ${ }^{2}$ 2008. (Urfelder Reihe 7). p. 32. 
tornar-se co-responsável por este processo de construir uma comunidade mais fraterna e igualitária, na qual todos devem ter reconhecida sua dignidade de filhos e filhas do mesmo Pai. Por isso, Jesus declara abençoados pelo Pai os que fazem o bem aos necessitados (Mt 25,34-36), sendo os caridosos compassivos como o Pai é compassivo (Lc 6,36).

No segundo momento, é importante destacar a fé de Jesus na prevalência do reinado e, com isso, da vontade do Pai celeste. A segunda e terceira preces do Pai-nosso girarão em torno deste tema: Venha teu reino, seja feita tua vontade (Mt 6,10). Em todo caso, para Jesus é certo que toda planta não plantada pelo Pai celeste será arrancada (Mt 15,13). Ou seja, nenhuma realidade impor-se-à definitivamente contra a vontade do Pai (Mt 10,29). Em contrapartida, a pessoa pode ser exigida até o extremo pelo Pai. Neste sentido, Jesus entregou sua vida voluntariamente pelos outros, compreendendo sua morte como mandamento recebido do Pai (Jo 10,17-18). Por mais que tenha confiado na possibilidade de tomar sua vida de volta, nada anulou sua dor e seu sofrimento. Mesmo assim, por meio da oração, Jesus ganhou firmeza e coragem de enfrentar a situação dramática: Meu Pai, se não for possível que este cálice passe de mim sem que eu o beba, seja feita tua vontade! (Mt 26,42).

Ao pensar, junto aos Evangelhos, sobre Jesus e seu relacionamento com o Pai celeste, tudo culmina num terceiro ponto. Jesus é, por excelência, o Filho. Basta contemplar as seguintes palavras dele: Tudo me foi dado pelo Pai. Ninguém conhece o Filho senão o Pai; e ninguém conhece o Pai senão o Filho, e aquele a quem o Filho quiser revelá-lo (Mt 11,27; Lc 10,22). De um modo particular, o evangelista João medita o relacionamento entre o $P a i$ e o Filho. Afirma que o Pai ama o Filho, porque este último dá sua vida (Jo 10,17). Mais ainda: o Pai mostra ao Filho tudo o que ele mesmo faz (Jo 5,20). Ou seja: ao permanecer no Filho, o Pai realiza suas obras (Jo 14,10). Afinal, o Pai vivo enviou o Filho e o Filho vive através do Pai (Jo 6,57). Além do mais, o Filho fala o que o Pai Ihe diz (Jo 12,49-50), pois o Filho, por si mesmo, nada faz, mas realiza só aquilo que vê o Pai fazer (Jo $5,19)$. Surge dessa forma, um relacionamento mútuo de maior intensidade: $o$ Pai ama o Filho (Jo 3,35; 5,20; 10,17; 15,9) e o Filho ama o Pai (Jo 14,31). Ou, com outras palavras: por ter observado os mandamentos do Pai, o Filho permaneceu no amor dele (Jo 15,10). Com isso, faz-se presente o seguinte mistério: o Pai está no Filho e o Filho está no Pai (Jo 10,38; 14,11; 17,21). 
Justamente deste pensamento, porém, nasce outra realidade de grande importância: Quem reconheceu Jesus, conhece o Pai (Jo 14,7). E mais ainda: Aquele que ama o Filho, observando os mandamentos dele, será amado pelo Pai (Jo 14,21). Ou, ao contrário: Quem não honra o Filho, também não honra o Pai que o enviou (Jo 5,23).

Resumindo: ao chamar Deus de Pai, seguindo o convite de Jesus, é bom lembrar-se do que este último ensinou sobre o Pai. Trata-se de um Pai providente que se preocupa conosco. A vontade e o reinado deste Pai vão se impor no decorrer da história. Além disso, surge a possibilidade extraordinária de chegar ao Pai através de Jesus, pois quem viu o Filho viu o Pai (Jo 14,7-9).

\section{O ÚNICO PAI}

Dentro da história de Jesus e de sua proposta de seguimento, a ideia de Deus ser Pai ganha ainda outra conotação importante. Os discípulos, pois, quando foram chamados por Jesus, deixaram o pai deles (cf. Mc 1,1920; Mt 4,21-22). Ficaram sem proteção. De repente, estavam fora do único sistema social que era a família ao redor do pai. Jesus, por sua vez, Ihes oferece outro pai. Mais ainda: convida os discípulos a chamarem exclusivamente Deus de Pai: A ninguém na terra chameis 'Pai', pois só tendes o Pai celeste (Mt 23,9).

\section{O CÉU COMO LUGAR DO PAI}

Na visão religioso-cultural do Antigo Israel, céus e terra - as duas partes do cosmo - pertencem a Deus, uma vez que este último os criou no início (Gn 1,1). Jesus também defende a ideia de que o Pai é o Senhor do céu e da terra (Mt 11,25).

O céu é visto como lugar onde o Senhor Deus mora (SI 2,4), ou seja, onde está o trono dele (SI 103,19). Justamente deste lugar - que está bem acima da terra e de onde se enxerga tudo -, os olhos de Deus observam e as pupilas dele examinam os filhos de Adão (SI 11,4).

Além do mais, ao imaginar que o Pai está nos céus, cria-se uma separação no sentido de SI 115,16: O céu é o céu do Senhor; a terra, porém, 
ele deu aos filhos de Adão. Portanto, existe uma distância essencial entre o homem na terra e quem mora no céu. Ou seja, Deus, ao ultrapassar todos os limites que se impõem ao homem, precisa ser reconhecido como infinitamente grande, soberano, poderoso e onisciente. ${ }^{5}$ Mais ainda: a expressão nos céus "previne banalizar o Pai-Nosso ou esvaziá-lo cá embaixo". ${ }^{6}$

Em contrapartida, por mais que exista uma distância considerável entre Deus e o ser humano, aquele que mora nos céus pode ser experimentado como Pai por quem mora na terra. Abre-se, sobretudo na pessoa de Jesus, a possibilidade para o homem de um relacionamento com Deus, pois quem ama Jesus será amado pelo Pai (Jo 14,21). Ou, com outras palavras: "Jesus é, no sentido próprio, o Filho, tendo a mesma natureza do Pai. E ele quer nos integrar em sua humanidade e, desta forma, em sua filiação, quer dizer, na pertença total a Deus". ${ }^{7}$

Resta lembrar ainda outra circunstância destacada por Jesus como absolutamente central: o reinado do Pai que está nos céus abrange também a terra dada aos filhos de Adão. Afinal, Jesus apresenta, com urgência, a necessidade de que as coisas se deem assim na terra como no céu (Mt 6,10), expressão usada no centro do Pai-Nosso. Ou, com outras palavras: por mais que, no início da oração ensinada por Jesus, se imagina Deus nos céus, isto não significa que ele não estivesse também presente na terra. Pelo contrário: o Senhor nosso Deus está no céu e na terra, pois ele se enaltece para assentar-se em seu trono celeste e se abaixa para ver os homens na terra, em especial, os mais necessitados entre nós (SI 113,4-9).

\section{Dr. Matthias Grenzer \\ é professor doutor de Teologia Bíblica na Faculdade de Teologia Nossa Senhora da Assunção - PUC-SP.}

5 Cf. Johannes Marböck, Céu, p. 57. In: Johannes B. Bauer, Dicionário Bíblico-Teológico. São Paulo, Loyola, 2000. p. 56-58.

6 Franz Zeilinger, Entre o céu e a terra. Comentário ao Sermão da Montanha (Mt 5-7). São Paulo, Paulinas, 2008. (Bíblia e História - Série Maior). p. 182.

7 Joseph Ratzinger / Benedikt XVI, Das Vaterunser. Meditationen über das Gebet des Herrn aus "Jesus von Nazareth". Freiburg, Herder, 2008. p. 33. 